\title{
Dinamometer Untuk Alat Uji penarikan Kawat (Perancangan, Pembuatan dan Pengujian)
}

\section{Dynamometer for Wire Retraction Test Equipment (Design, Manufacture and Testing)}

\author{
Sir Anderson \\ Jurusan Teknik Mesin Politeknik Negeri Padang Kampus Limau Manis Padang 25163 \\ Telp. 0751-72590 Fax. 0751-72576 Email: siranderson72@yahoo.co.id
}

\begin{abstract}
The basic principle of metal formation is to change shape by giving an external force so that plastic deformation occurs. One example of this formation is wire drawing. The important parameter in wire drawing is the drawing force, which is the force needed to deform the wire to produce the desired reduction. The measurement of withdrawal force is carried out through a wire drawing test equipped with a dynamometer, which consists of load cell and strain gauge. From this test, the withdrawal force can be measured as an electrical quantity that can be read using a multitester or computer. For wire drawing testing dynamometers are designed and made as measuring sensors for withdrawal forces on a laboratory scale. From the results of testing with a dynamometer the average wire drawing force for copper reduction I was $72.88 \mathrm{kgf}$, copper reduction II was $95.88 \mathrm{kgf}$ and brass was $126.50 \mathrm{kgf}$. The price of this test is greater than the theoretical price
\end{abstract}

Keywords: Wire, Drawing, Force, Dynamometer

\section{PENDAHULUAN}

Salah satu contoh teknik pembentukan logam adalah penarikan kawat (wire drawing). Dengan penarikan kawat ini didapatkan kawat berkekuatan tinggi, dan diameter kawat sesuai dengan yang diinginkan.

Parameter yang penting dalam penarikan kawat adaiah gaya penarikan kawat. Gaya penarikan adalah gaya yang dibutuhkan untuk mendeformasi kawat agar menghasilkan reduksi yang diinginkan.

Untuk mengukur gaya penarikan kawat dilakukan dengan menggunakan peralatan tambahan seperti dinamometer, load cell dan lain-lain,

Pada penelitian ini dibuat dinamometer berbentuk ring. Dinamometer ring ini merupakan suatu alat pengukur gaya terdiri dari komponen utama berupa sel beban (load cell).

Tujuan penelitian Merancang dan membuat dinamometer untuk pengujian penarikan kawat. Dinamometer ini berbentuk ring yang merupakan suatu alat pengukur gaya berupa sel beban (load cell). Sel beban (load cell) mempunyai beberapa bentuk diantaranya link, beam., ring. Penggunaan masing-masing load cell ini tergantung kepada kebutuhan (bentuk pembebanan). Untuk pengujian penarikan kawat load cell yang digunakan adalah yang berbentuk ring.

Lingkup penelitian, perancangan dan pembuatan dinamometer yang dilanjutkan dengan pengujian dengan multimeter digital. Pengujian ini menghasilkan besaran listrik berupa tegangan (voltage). Pengujian penarikan kawat ini juga menggunakan multimeter digital.

Asumsi Perancangan dinamometer dirancang berbentuk ring dan sensor yang digunakan adalah strain gage dengan asumsi;

a. Material ring homogen dengan modulus elastisitas sama untuk setiap bagian.

b. Analisis tegangan dianggap dua dimensi.

c. Beban tarik pada ring dianggap satu sumbu. 
d. Penambahan beban pada pengujian dilakukan secara perlahan-lahan sehingga beban penarikan yang bekerja dapat dianggap bebaan statik.

e. Material strain gage lebih elastis daripada material ring.

\section{Proses-proses Pengerjaan Logam}

Peran logam penting pada teknologi modern terutama disebabkan kemudahan pembentukannya menjadi bentuk-bentuk yang berguna. Prinsip dasar pembentukan logam adalah melakukan perubahan bentuk pada benda kerja dengan cara memberikan gaya luar sehingga terjadi deformasi plastis. Contohnya : pengerolan (rolling), tempa (forging), ekstrusi (extruding), penarikan kawat (wire drawing) dan lain-lain.

Proses-proses pengerjaan logam antara lain :
a. Teknik Pengecoran (Casting)
b. Teknik Pembentukan (Forming)
c. Teknik Pemesinan (Machining)
d. Teknik Pengelasan (Casting)
e. Perlakuan Panas (Heat Treatment)
f. Perlakuan Permukaan (Surface
Treatment)

Empat proses pertama mengubah bentuk benda kerja dengan ciri-ciri proses yang berbeda satu dengan yang lainnya. Pada proses pengecoran, logam cair dituangkan ke dalam cetakan. Logam cair sejauh mungkin mengisi rongga cetakan, sehingga setelah membeku diharapkan bentuk benda kerjanya akan sama dengan rongga cetakan.

Proses pemesinan adalah mengubah bentuk benda kerja dengan cara membuang sebagian logam dalam bentuk geram (chips).

Yang dimaksud dengan proses pengelasan adalah penyambungan dua logam dengan pencairan sebagian dari daerah logam yang akan disambung. Dengan adanya proses pencairan dan pembekuan di daerah tersebut menyebabkan terjadinya ikatan sambungan.
Perbedaan proses peinbentukan dengan proses yang lain yaitu :

a. Proses pengecoran.

Pemanasan dilakukan hingga logarn mencair, sedangkan pada pengerjaan panas (hot working) pemanasan yang dilakukan untuk memudahkan terjadinya deformasi plastis.

b. Proses pemesinan.

Pada proses pemesinan ini menghasilkan geram,sedangkan proses pembentukan tidak

c. Proses pengelasan.

Pencairan sebagian dari daerah logam yang akan disambung.

Dalam membuat suatu benda kerja biasanya dilakukan beberapa proses atau proses tersebut merupakan alternatif (pilihan).

Tujuan proses pembentukan logam yang utama ada dua yaitu :

a. Mengubah bentuk benda kerja menjadi bentuk yang dikehendaki.

b. Memperbaiki sifat logam dengan cara memperbaiki struktur mikronya dengan menghomogenkan dan menghaluskan butir, menutup rongga cacat coran serta meningkatkan kekuatan logam dengan mekanisme strain hardening.

\section{Klasifikasi proses pembentukan logam.}

Dalam industri digunakan berpuluhpuluh jenis proses pembentukan logam. Untuk memudahkan pengkajian, maka proses-proses tersebut diklasifikasikan dengan beberapa cara, yaitu :

- Berdasarkan daerah temperatur pengerjaan

- Berdasarkan jenis gaya pembentukan

- Berdasarkan bentuk benda kerja

- Berdasarkan tahapan produk

\section{Klasifikasi berdasarkan temperatur pengerjaaan}

Menurut temperatur pengerjaannya, proses pembentukan dibagi 2, yaitu :

- Pengerjaan panas (Hot Working)

- Pengerjaan dingin (Cold Working)

Jika ditinjau dari segi metalurgi batasan dari kedua pengerjaan ada atau tidaknya 
proses pemanasan, hal ini tidak sepenuhnya benar. Batasan sebenarnya bedasarkan pada temperatur rekristalisasi.

Proses pengerjaan panas adalah proses pembentukan yang dilakukan pada daerah temperatur rekristalisasi. Dalam temperatur rekristalisasi terjadi peristiwa pelunakan terus menerus sehingga mudah dideformasi (deformasi yang diberikan kecil). Karena sifat lunak dan ulet mengakibatkan gaya pembentukan yang dibutuhkannya relatif kecil, sehingga benda kerja mampu menerima deformasi yang besar tanpa terjadi retak.

Proses pengerjaan dingin adalah proses pembentukan yang dilakukan dibawah temperatur rekristalisasi. Dalam praktek memang pada umumnya dilakukan pada temperatur kamar (tanpa pemanasan benda kerja). Disini terjadi peristiwa strain hardening (pengerasan regangan) yaitu logam akan bersifat makin kuat dan makin keras, tetapi makin getas bila dideformasi sehingga mudah terjadinya retak.

\section{Klasifikasi berdasarkan pembentukan}

gaya

- Pembentukan dengan tekanan Pada daerah deforrnasi bekeria tegangan-tegangan tekan, Contohnya :

- tempa (forging)

- pengerolan (rolling)

- Pembentukan dengan tekanan dan tarikan

Pada daerah deformasi bekerja tegangan tekan dan tegangan tarik. Gaya yang diberikan adalah gaya tarik, menyebabkan timbulnya gaya tekan dari perkakas terhadap daerah deformasi. Contoh:

- penarikan kawat (wire drawing)

- penarikan pipa (tube drawing)

- penarikan dalam (deep drawing)

- Pembentukan dengan tarikan.

Perubahan bentuk yang terjadi di daerah deformasi disebabkan oleh tegangan tarik. Contohnya: tarik regang (stretching).

- Pembentukan dengan tekukan. Contohnya: proses tekuk (bending)
- Pembentukan dengan geseran (guntingan)

Pengguntingan melibatkan gaya geser (gaya gunting) yang cukup besar untuk memotong pada bidang geser

\section{Klasifikasi berdasarkan bentuk benda kerja}

Berdasarkan bentuk benda kerjanya, proses pembentukan logam dapat dibagi 2, yaitu :

- Pembentukan benda kerja masif atau pejal.

Ciri utamanya adalah terjadinya perubahan tebal benda kerja selama diproses. Contohnya:

- pengerolan

- tempa

- penarikan kawat

- Pembentukan benda kerja pelat

Disini benda kerjanya adalah pelat yang dideformasi menjadi bentuk tertentu, tebalnya dapat dianggap tetap. Contohnya:

- penarikan dalam

- dan lain-lain

Klasifikasi berdasarkan tahapan produk. Perbedaannya adalah dalam menghasilkan produk, yaitu :

- Proses pembentukan primer.

Proses yang menghasilkan produkproduk setengah jadi. Contohnya:

- pengerolan yang menghasilkan pelat.

- ekstiusi yang menghasilkan batang.

- Proses pembentukan sekunder.

Proses ini adalah proses lebih lanjut hasil dari proses primer menjadi bentuk akhir. Contohnya:

- penarikan kawat, diproses menjadi kavvat yang diameternya lebih kecil.

- penarikan dalam memproses pelat menjadi bentuk tabling.

\section{Analisa Gaya Pembentukan.}

Perencanaan proses pembentukan selain meninjau teknologi proses, aspek metalurgis pada benda kerjanya, perkiraan besarnya gaya pembentukan, serta 
mendapatkan ukuran besarnya mesin ataupun peralatan yang diperlukan.

Analisa tegangan pada proses pengerjaan logam merupakan bidang plastisitas yang banyak diteliti selama 50 tahun terakhir ini. Karena gaya dan deformasi pada umumnya cukup rumit, biasanya digunakan asumsi penyederhanaan untuk mendapatkan penyelesaian. Karena regangan yang terlibat dalam proses deformasi adalah besar, biasanya regangan elastis dapat diabaikan dan yang diperhatikan hanya regangan plastisnya. Sebagai pendekatan pertama, pengerasan regang dapat diabaikan dan yang diperhatikan hanya regangan. Pada pengerjaan panas, hal demikian dapat diterima Selain itu bahan dianggap isotropik dan homogen. Biasanya deformasi logam dalam cetakan tidaklah seragam. Masalah utama adalah cara untuk memperoleh gambaran yang tepat mengenai ketidak seragaman deformasi dan perhitungan tegangan lokal. Akhir-akhir ini telah dicapai kemajuan pesat berkat penerapan metode elemen hingga pada permasalahan plastisitas skala besar.

Kajian analitis proses pembentukan logam adalah menentukan gaya-gaya yang diperlukan sehingga menghasilkan deformasi tertentu dari suatu bentuk geometri. Perhitungan-perhitungan demikian sangat berguna untuk memilih atau merancang peralatan-peralatan yang diperlukan. Teori yang ada umumnya sudah cukup memadai. Persoalan yang tak kurang pentingnya adalah peramalan batas deformasi sebelum terjadi perpatahan. Pada umumnya, teori mengenai batas kemampuan bentuk dan kriteria patah belum berkembang sepenuhnya.

Sebelum melangkah terlalu jauh, sebaiknya kita tinjau kembali dasar-dasar teori plastisitas. Hubungan yang paling mendasar untuk deformasi plastis adalah hubungan volume konstan. Seringkali tegangan-tegangan dan regangan tekan memegang peran utama pada proses pembentukan logam. Jika balok dengan tinggi awal $h_{0}$ ditekan menjadi $h_{1}$ regangan tekan aksial akan menjadi.

$$
\begin{aligned}
& \text { Regangan sesungguhnya: } \\
& \varepsilon=\int_{h_{1}}^{\hat{h}_{1}} \frac{d h^{2}}{\hbar}=\ln \frac{\hbar_{1}}{\hbar_{0}}=-\ln \frac{h_{0}}{\hbar_{1}}
\end{aligned}
$$$$
h_{0}>h_{1}
$$

Regangan konvesional :

$$
e=\frac{\mathbb{h}_{1}-h_{0}}{\mathfrak{h}_{0}}=\frac{\mathbb{k}_{1}}{\mathfrak{k}_{0}}-1
$$

Regangan yang didapatkan adalah negatif, ini menunjukkan bahwa regangannya adalah regangan tekan. Tetapi pada pembentukan logam, tegangan dan regangan tekan dinyatakan positif Bila menggunakan konvensi ini, maka harus digunakan subskrip c. Jadi, regangan diatas dinyatakan dengan :

$$
\begin{aligned}
& \varepsilon_{0}=\ln \frac{\hbar_{0}}{h_{1}} \\
& e_{0}=\frac{\hbar_{0}-\hbar_{1}}{\hbar_{0}}=1-\frac{\hbar_{1}}{\hbar_{0}}
\end{aligned}
$$

Deformasi pembentukan logam sering dinyatakan sebagai pengurangan luas penampang lintang. Perbandingan pengurangan diberikan oleh persamaan :

$$
r=\frac{A_{0}-A_{1}}{A_{0}}
$$

Dari hubungan volume konstan diperoleh :

$$
\begin{aligned}
& \mathrm{A}_{1} \mathrm{~L}_{1}=\mathrm{A}_{0} \mathrm{~L}_{0} \\
& r=1-\frac{A_{1}}{A_{0}} \\
& \varepsilon=\ln -\frac{{\frac{L_{1}}{1}}_{L_{0}}}{L_{0}}=\ln \frac{A_{0}}{A_{1}}=\ln \frac{1}{1-r}^{A_{0}}=1-r
\end{aligned}
$$

Untuk memperkirakan besarnya gaya pembentukan telah dikembangkan beberapa teori atau metoda analisa, dengan derajat kerumitan yang makin tinggi dan kemampuan meramalkan lebih cermat Teori atau metoda yang telah dikembangkan untuk memecahkan masalah plastisitas tersebut adalah :

- Teori Elementer (metoda slab)

Disini diasumsikan bahwa distribusi tegangan pada penampang adalah seragam (uniform).

- Teori medan garis slip (slip-line field theory)

Teori ini digunakan untuk menganalisa proses deformasi yang bersifat regangan bidang (plane strain) terhadap material yang tidak mengalami pengerasan

- Metoda energi (energy method).

Metoda energi ini adalah yang paling unggul untuk menganalisa proses 
pembentukan logam. Metode ini didasarkan pada prinsip bahwa kerja atau usaha yang termasuk oleh adanya gaya luar adalah sama dengan energi deformasi pada material benda kerja

- Metoda elemen hingga (Finite elemen method)

Metoda eleinen hingga ini diterapkan untuk daerah deformasi elastic-plastis Dengan menggunakan metode energi deformasi seragam. Perhatikan kasus silinder yang diberi beban tarik. Kenaikan kerja yang dibutuhkan untuk menambah panjang $\delta \mathrm{L}$ adalah :

$$
\begin{aligned}
& \delta W=\delta P \delta L=\bar{\sigma} A \delta L / 4 / \\
& \text { dimana } \bar{\sigma} \quad \text { adalah tegangan luluh }
\end{aligned}
$$
rata-rata. Energi deformasi tiap satuan volume

$$
\frac{\partial W}{V}=\frac{\sigma A}{A} \frac{\partial L}{L}=\bar{\sigma} \frac{\partial L}{L}
$$

Kerja plastis deformasi tiap satuan volume adalah :

$$
U_{p}=\bar{\sigma} \int d \varepsilon=\bar{\sigma} \int \frac{\partial L}{L}=\bar{\sigma} \frac{L_{1}}{L_{0}}
$$

Jika kita terapkan minus ini untuk menarik kawat bulat dari luas $A_{b}$ menjadi luas $\mathrm{A}_{\mathrm{a}}$

$$
\begin{aligned}
& \mathrm{W}=\mathrm{P}_{\mathrm{a}} \mathrm{L}_{\mathrm{a}}=\mathrm{U}_{\mathrm{p}} \mathrm{V}=\mathrm{A}_{\mathrm{a}} \mathrm{L}_{\mathrm{a}} \bar{\sigma} \ln \frac{L_{\mathrm{a}}}{L_{\mathrm{b}}} \\
& \mathrm{P}_{3}=\mathrm{A}_{\mathrm{a}} \bar{\sigma} \ln \frac{L_{\mathrm{am}}}{L_{\mathrm{b}}} \mathrm{P}_{3}=\mathrm{A}_{3} \bar{\sigma} \ln \frac{A_{\mathrm{b}}}{A_{\mathrm{a}}}
\end{aligned}
$$

Tegangan tarik adalah :

$$
\begin{aligned}
\sigma_{x a} & =\frac{P_{a}}{A_{a}}=\bar{\sigma} \ln \frac{A_{b}}{A_{a}} \\
\sigma_{x a} & =\bar{\sigma} \ln \frac{1}{1-r}
\end{aligned}
$$

Persamaan (2.6) tidak hanya mengabaikan gesekan, tetapi juga mengabaikan pengaruh tegangan melintang.

Jumlah kerja sesungguhnya persatuan volume pada proses deformasi melebihi nilai yang diberikan dalam persamaan (2.5). Disamping kerja deformasi ideal $\mathrm{U}_{\mathrm{f}}$, ada pula sejumlah kerja untuk mengatasi gesekan pada permukaan antara logam-die sebesar $U_{f}$ dan kehilangan kerja lebih sebanyak $\mathrm{U}_{\mathrm{f}}$. Kerja lebih adalah kerja yang melibatkan proses pergeseran internal akibat deformasi tidak seragam yang tidak berperan dalam mengubah bentuk benda kerja. Besarnya $\mathrm{U}_{\mathrm{f}}$ tergantung pada geometri proses dan gesekan. Jadi besarnya kerja total adalah :

$$
\mathrm{U}_{\mathrm{T}}=\mathrm{U}_{\mathrm{p}}+\mathrm{U}_{\mathrm{f}}+\mathrm{U}_{\mathrm{r}} / 4 /
$$

Eflsiensi proses dapat dinyatakan sebagai

$$
\eta=\frac{U_{F}}{U_{T}} / 4 /
$$

\section{Penarikan Kawat}

Operasi penarikan meliputi penarikan logam melalui cetakan oleh gaya tarik yang bekerja pada bagian keluar cetakan. Aliran plastis terutama disebabkan oleh gaya tekan yang timbul sebagai reaksi dari logam terhadap cetakan. Pengurangan diameter batang / kawat dengan cara penarikan berturutan dinamakan penarikan batang / kawat, tergantung kepada diameter produk akhir yang dihasilkan.

Penampang melintang suatu cetakan tarik atau poci tarik kerucut tampak pada gambar dibawah. Tempat masuk cetakan berbentuk sedemikian rupa sehingga kawat yang masuk poci akan menarik pelumas sekaligus. Bentuk lonceng meningkatkan tekanan hidrostatik dan memindahkan aliran.pelumas..S.udue đàtang adalah bagian dari cetakan utama terjadi reduksi diameter. Sudut setengah cetakan $\alpha$ merupakan parameter proses yang penting. Daerah bantalan tidak menghasilkan reduksi akan tetapi menambah gesekan pada kawat. Fungsi utama daerah bantalan adalah memungkinkan dibersihkannya permukaan konis tanpa perubahan dimensi cetakan keluar. Tirus belakang (back relief) memüngkinkan bähan mengembang sedikit sewaktu kawat keluar dari cetakan. Pada saat ini sebagian besar poci tarik dibuat dari karbida tungsten, atau intan pada proses industri (untuk kawat halus). Mata tarik atau (die nib) terletak dalam dudukan baja yang tebal. 


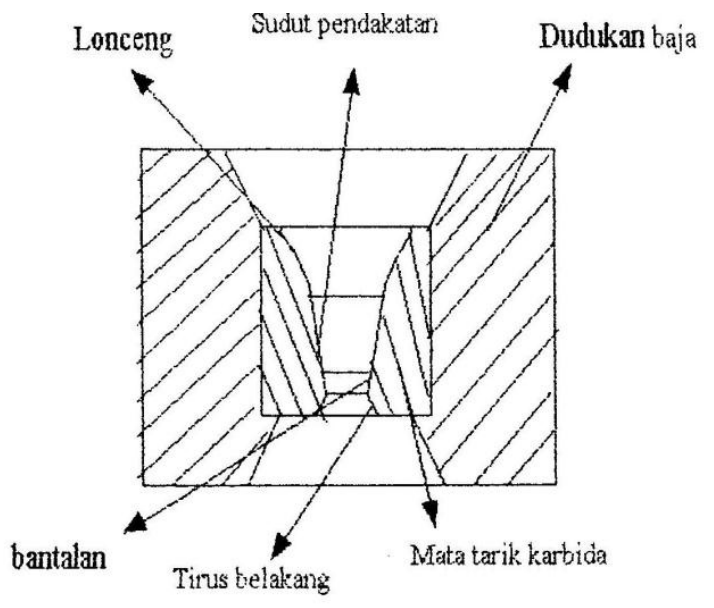

Gambar 1.

Perbedaan antara kawat dan batang kurang jelas, umumnya istilah kawat digunakan untuk produk berdiameter kecil dari $5 \mathrm{~mm}$.

Pada proses industri, penarikan kawat dimulai dengan pengerolan panas batang kawaL Mula-mula. batang dibersihkan untuk menghilangkan kerak yang dapat mengakibatkan cacat permukaan dan keausan cetakan yang berlebihan. Tahap berikutnya adalah persiapan batang agar pelumasan efektif Untuk menghasilkan kawat berkekuatan tinggi, diperlukan pelapisan yang hinak dengan kapur atau lapisan tipis atau timah putih, Selain itu sering pula digunakan lapisan konversi seperti sulfat atau oksalat Balian ini dipergunakan disamping pelunias.

Bila diameter batang cukup kecil sehingga dapat digulung, gunakan blok penggulung dan ruang yang diperlukan tidak terlalu luas, sebab umwnnya reduksi penampang setiap pas tarik tidak lebih dari 30-35\%, diperlukan reduksi ganda untuk mencapai reduksi keseluruhan. Mesin blok ganda dengan satu cetakan dan satu blok tarik untuk setiap reduksi secara umum. Karena diameter kawat berkurang setelah melalui pas tertentu, kecepatan dan panjang kawat bertambah. Jadi kecepatan setiap blok tarik harus bertambah besar agar tidak terjadi slip antara kawat dan blok. Hal ini dapat dicapai bila kecepatan setiap blok tank dikendalikan oleh motor tersendiri. Akan tetapi untuk menghemat energi digunakan satu motor listrik untuk menjalankan kerucut bertingkat. Diameter setiap kerucut dirancang sedemikian sehingga kecepatannya sebanding dengan reduksi penampang tertentu. Bila kecepatan kawat dan kecepatan blok gulung tidak sesuai, kawat menggeser pada blok sewaktu berputar dan menyebabkan terjadinya gesekan dan panas. Kecepatan tarik pada mesin cetakan ganda dapat mencapai 600 $\mathrm{m} /$ menit untuk penarikan kawat besi/baja dan 2000 m/menit untuk kawat bukan besi.

Timbulnya panas pada operasi tarik suatu masalah umum. Meskipun penarikan batang atau kawat biasanya dilakukan secara dingin deformasi plastik dan gesekan akan menaikkan temperatur kawat hingga beberapa ratus derajat ceicius. Sebagian dari panas tadi dilepaskan pada pendinginan antar pas dan karena panas yang diserap cetakan sedikit sekali, kenaikan suhu cukup besar.

Kawat bukan besi dan kawat baja karbon rendah, dihasilkan dalam sejumlah temper yang bervariasi dari yang sangat lunak hingga yang sangat keras. Kadangkadang diperlukan proses pelunakan yang setara, tergantung padajenis logam dan reduksi yang diinginkan.

Cacat yang terjadi pada kawat dan batang dihasilkan oleh cacat pada batang mula (kampuh, potongan-potongan atau cacat pipa) atau akibat proses deformasi. Tipe cacat penarikan yang umum adalah: pecah sentral atau cetakan cevron. Hal ini dinamakan "cupping", Analisis batas atas mampu mengidentifikasi kombinasi sudut setengah cetak dan reduksi., jika berbentuk rongga ditengah, maka diperlukan energi deformasi yang lebih kecil.

\section{Analisis Penarikan Kawat}

Walaupun penarikan kawat nampaknya proses pengerjaan logam yang paling sederhana, analisis lengkap yang dapat menentukan gaya tarik dengan ketelitian \pm $20 \%$, merupakan persoalan yang agak sukar. Kita akan menggunakan penarikan kawat sebagai suatu contoh bagaimana cara membina model untuk mendekati keadaan sebenarnya. 
Pendekatan harga tegangan tarik dengan menggunakan metode energi deformasi seragam dengan persamaan :

$$
\sigma_{x a}=\sigma_{0} \ln -\frac{A_{b}}{A_{a}}=\sigma_{0} \ln \frac{1}{1-r} / 4 /
$$

Persamaan ini tidak hanya mengabaikan gesekan, tetapi juga mengabaikan pengaruh tegangan melintang dan deformasi yang berlebihan.

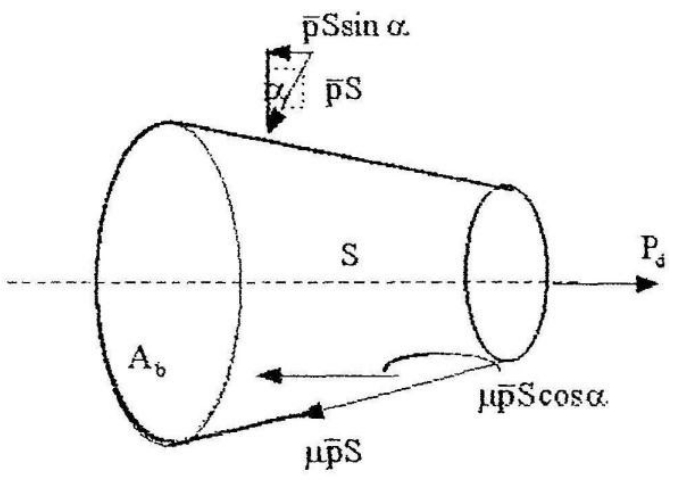

Gambar 2.

Analisis yang hampir sama untuk penarikan kawat telah dilakukan oleh Johnson dan Rowe. Luas permukaan kontak antara kawat dan cetakan adalah

$$
S=\frac{A_{b}-A_{a}}{\sin \alpha} / 4 /
$$

dan tekanan normal rata-rata pada luas tersebut adalah p. Gaya yang bekerja dalam arah aksial ditunjukkan pada gambar diatas. Gaya tarik $\mathrm{P}_{\mathrm{d}}$ diimbangi oleh komponen horisontal gaya gesekan dan komponen horisontal tekanan normal.

$\mathrm{P}_{\mathrm{d}}=\mu \bar{p} S \cos \alpha+\bar{p} S \sin \alpha$

$\mathrm{P}_{\mathrm{d}}=$

$\bar{p}\left(A_{b}-A_{a}\right)(\mu \cot \alpha+1)=\bar{p}\left(A_{b}-\right.$

$\left.A_{a}\right)(1+B)$

$$
\mathbf{P}_{\mathrm{d}}=\bar{\sigma} \mathrm{A}_{\mathrm{a}} \ln \frac{A_{\mathrm{b}}}{A_{\mathrm{a}}}(1+B)
$$

\section{METODOLOGI}

\section{Perancangan Ring Dinamometer}

Load cell (sel beban) mempunyai beberapa bentuk diantaranya link, beam dan ring. Penggunaan masing-masing load cell ini tergantung kepada kebutuhan (bentuk pembebanan). Load cell ini berbentuk ring yang digunakan untuk pengujian pada penarikan kawat. Ring dinamometer ini merupakan sebuah trandaser untuk mengukur gaya yang diberikan (gaya penarikan kawat). Sedangkan sebagai sensor atau perasa perubahan elastis pada ring dinamometer ini digunakan strain gauge.

Gaya penarikan yang diberikan akan diteruskan pada setiap bagian dalain ring berbentuk gaya normal, gaya geser dan momen lentur. Gaya normal dan momen akan menghasilkan tegangan normal dalam ring. Pengukuran tegangan normal yang terjadi dapat dilakukan dengan pemasangan strain gauge pada ring.

Strain gauge dipasangkan pada permukaan yang mengalami tegangan normal maksimum supaya sinyal yang dihasilkan dapat maksimum serta dapat mengontrol posisi gagal dari ring. Ring akan gagal bila mengalami pembebanan di atas daerah elastis (deformasi plastis).

\section{Variabel-variabel Perancangan Ring Dinamometer.}

Variabel-variabel yang membatasi perancangan dimensi ring dinamometer ini adalah :

1. $\mathrm{K}_{\mathrm{s}}$ (sensitifitas regangan). Strain gauge yang digunakan adalah jenis FLA-5-3L11 dengan $\mathrm{K}_{\mathrm{s}}=2,14$,tahanan 120,3 \pm $0,5 \%$ ohm dan panjang $5 \mathrm{~mm}$.

2. Gaya penarikan maksimum P. Gaya penarikan dirancang dari ukuran standar spesimen dengan diameter 3,5 $\mathrm{mm}$. Dengan mengambil kekuatan tarik maksimum material adalah 100 $\mathrm{kgf} / \mathrm{mm}^{2}$ maka :

$$
\begin{aligned}
& \sigma_{\text {tarik mak }}=100 \mathrm{kgf} / \mathrm{mm}^{2} \\
& \sigma=P / \mathrm{A} \\
& P=\sigma . \mathrm{A} \\
& =100 \cdot\left(\pi \cdot 3 \cdot 5^{2}\right) / 4 \\
& =962,11 \mathrm{kgf}(\text { dibulatkanmenjadi }
\end{aligned}
$$
$1000 \mathrm{kgf}$ atau $10000 \mathrm{~N}$ )

3. Tegangan keluaran dan masukan pada rangkaian strain gauge (Eo dan E,) adalah :

$$
\begin{aligned}
& \mathrm{E}_{0}=1,2 \mathrm{mV} \\
& \mathrm{E}_{1}=4200 \mathrm{mV}
\end{aligned}
$$

Kedua besaran merupakan variabel tetap dari strain gauge. Bila tegangan 
maksimum input melebihi nilai di atas menyebabkan strain gauge akan hangus (gagal). Tegangan keluaran $\mathrm{E}_{0}$ pada beban maksimum adalah 1,2 $\mathrm{mV}$.

4. Modulus elastisitas (E) ring. Bahan yang digunakan untuk membuat ring adalah ASSAB 705. Untuk berbagai jenis baja nilai modulus elastisitas dapat dianggap sama yaitu $200 \mathrm{GPa}(20.000$ $\mathrm{kgf} / \mathrm{mm}^{2}$ ).

Besar gaya penarikan maksimum adalah :

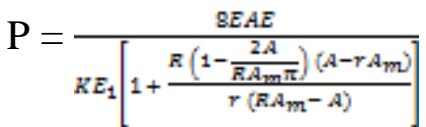

Dimensi dari ring didapatkan melalui iterasi pada persamaan 3.1 dengan harga $P$ yang telah ditetapkan. Besaran dimensi yang lain yaitu ;

- tebal ring (b)

- jari-jari luar $\left(\mathrm{R}_{0}\right)$

- jari-jari dalam $\left(\mathrm{R}_{1}\right)$

Dengan melakukan pemilihan terhadap dua besaran tetap misalnya $b$ dan $\mathrm{R} 0$, maka melalui proses iterasi harga $\mathrm{R} 1$ akan didapatkan. Pemilihan $b$ dan $R_{0}$ dengan iterasi juga dapat dilakukan, tergantung ukuran material yang tersedia. Besaran-besaran yang mempunyai harga tetap pada proses iterasi adalah :

- $\mathrm{P}=10000 \mathrm{~N}$

- $\mathrm{KB}=2,14$

- $\mathrm{E}_{0}=4200 \mathrm{mV}$. Dari hasil proses iterasi didapatkan :

- $\mathrm{R}_{0}=31 \mathrm{~mm}$ (dengan harga yang dibulatkan)

- $\mathrm{R}_{1}=45 \mathrm{~mm}$

- $b=20 \mathrm{~mm}$

\section{Pembuatan Ring Dinamometer}

Ring dinamometer ini dibuat dengan materialnya yaitu ASSAB 705. Pembuatan ring dinamometer ini dengan menggunakan mesin perkakas turning (bubut), drilling, boring.

Untuk membentuk ring dinamometer, material dipotong sesuai dengan ketebalan yang cocok untuk dipegang pada mesin perkakas. Setelah itu material dibubut untuk mendapatkan diameter luar ring dinamometer ini. Untuk membuat diameter dalam pada material dilakukan dengan mesin perkakas drilling. Lalu untuk memperbesar diameter dalam ring dinamometer sehingga sesuai dengan yang diinginkan maka dilakukan proses boring.

Proses akhir pembuatan ring dinamometer ini adalah pembuatan ulir pada bagian atas dan bawahnya. Pada ring ini digunakan ulir Ml2.

Setelah proses ini selesai maka strain gage direkatkan pada ring dinamometer ini sehingga.pengujian. daplat dilakukan.

\section{Alat Ukur Regangan}

Strain gauge digunakan mengukur regangan yang dipakai sebagai sensor pengukur gaya Strain gauge dipasang pada permukaan load cell yang mengalami tegangan normal maksimum, dengan menggunakan perekat khusus yang lebih kuat dari strain gauge sendiri. Pada daerah elastis logam terdapat hubungan linier antara tegangan dan regangan dalam bentuk persamaan :

$$
\sigma=\mathrm{E} . \mathrm{e} \text { atau } \mathrm{E}=\sigma / e \quad(\mathrm{E}=
$$

modulus elastisitas/modulus Young) (2.14)

Perubahan beban akan diikuti dengan perubahan regangan. Pada strain gauge, perubahan regangan menyebabkan perubahan tahanan dan perubahan tegangan keluaran.

Ada berbagai jenis strain gauge yang biasa digunakan untuk mengukur gaya, seperti : semi conduktor strain gauge, foil strain gauge dan wire strain gauge. Pada ring dinamometer ini digunakan strain gauge jenis foil. Alasannya adalah :

- Kepekaan (sensitivity) yang tinggi

- Mudah dalam pemasangan

- Mudah didapat

Pembuatan foil strain gauge dilakukan dengan photo etching. Sebuah lembaran logam yang sangat tipis (beberapa micron) dengan tahanan tertentu ditempelkan pada sebuah lembaran penyekat (isolator) listrik yang disebut "base". Penempelan dengan menggunakan perekat khusus. Untuk membuat bagianbagian yang diinginkan, lembaran logam 
dibentuk menjadi filamen (grid) melalui photo etching. Bagian yang tak perlu dibuang, grid yang tinggal berbentuk kawat-kawat halus sesuai bentuk yang diinginkan dengan dua ujung yang sengaja dibentuk lebih besar. Kedua ujung disambung dengan kabel yang disebut dengan gage lead. Konstruksi secara umum untuk strain gauge jenis foil dapat dilihat pada gambar 3 .

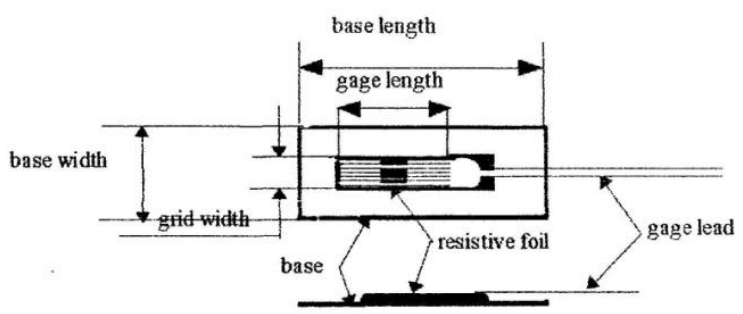

Gambar 3. Konstruksi strain gauge jenis foil

Ada bermacam-macam strain gauge yang tersedia dalam bebagai bentuk dan besar tahanan. Umumnya jenis foil mempunyai tahanan $120 \Omega$ dan untuk keperluan khusus dengan tahanan 350, 500, 1000 hingga $3000 \Omega$. Beberapa bentuk strain gauge jenis foil dapat dilihat pada gambar 4.

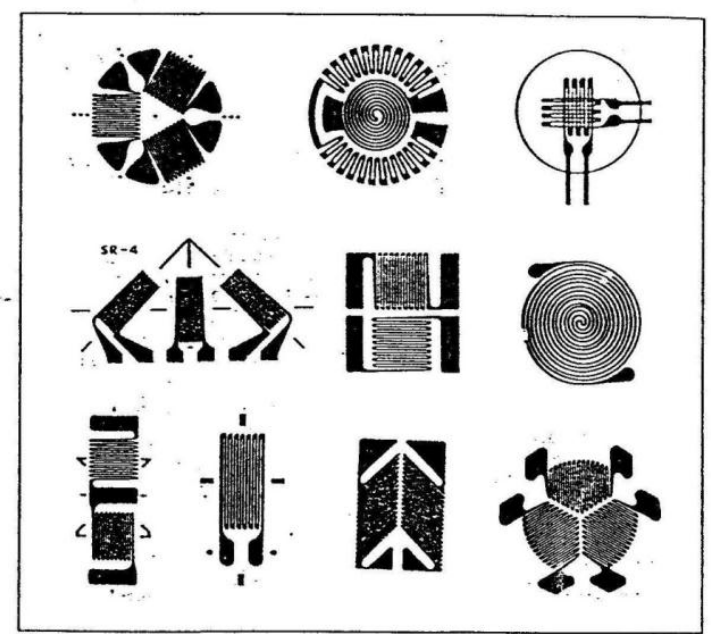

Gambar 4. Beberapa bentuk strain gauge jenis foil

\section{Prinsip Kerja Strain Gauge}

Strain gauge bekerja alas dasar perubahan tahanan listrik. Jika kawat logam yang memiliki tahanan jenis $\rho$, panjang $\mathrm{L}$ dan luas penarnpang A. maka tahanan $R$ ditulis sebagai :

$$
\mathrm{R}=\rho \frac{L}{A} / 4 /
$$

Bila kawat diberi tegangan maka akan terjadi dua regangan yaitu : regangan aksial $\varepsilon_{a}$ dan regangan lateral $\varepsilon_{1}$. Masingmasing regangan merupakan fungsi panjang dan diameter, seperti persamaan berikut :

$$
\begin{aligned}
& \varepsilon_{a}=\frac{\Delta L}{A}=\frac{L_{1}-L_{0}}{L_{0}} \\
& \varepsilon_{1}=\frac{\Delta d}{d}=\frac{d_{1}-d_{0}}{d_{0}}
\end{aligned}
$$

dengan d adalah diameter [mm] dan 1 paniana $[\mathrm{mm}]$. Perbandingan antara regangan lateral dan regangan aksial di kenal dengan perbandingan Poisson (Poison ratio) dan dengan bentuk persamaan ditulis :

$$
\mu=\frac{\varepsilon_{1}}{\varepsilon_{1}} / 1 / \text { persamaan }
$$

dideferensialkan (diturunkan) dalam bentuk perubahan tahanan kemudian disubstitusikan kedalam persamaan 3.3a dan $3.3 \mathrm{~b}$ akan meaghasilkan :

$$
\frac{\Delta R}{R}=\frac{\Delta \rho}{\rho}+\frac{\Delta L}{L}-\frac{\Delta A}{A}
$$

suku pertama merupakan perubahan tahanan jents, suku kedaa adalah regangan dan suku ketiga adalah reduksi penampang. Dua suku terakhir daput ditulis kembali sebagai fungsi regangan,

$$
\begin{aligned}
& \frac{\Delta p}{\rho}=m \frac{\Delta V}{V}=m(1+2 \mu) \frac{\Delta L}{L} \\
& \frac{\Delta A}{A}=2 \frac{\Delta d}{d}=-2 \frac{\Delta L}{L}
\end{aligned}
$$

maka diperoleh persamaan untuk perubahan tahanan sebagai berikut :

$$
\begin{aligned}
& \frac{\Delta R}{R}=(1+2 \mu) \frac{\Delta L}{L}+m(1+2 \mu) \frac{\Delta L}{L} \\
& \operatorname{atau} \\
& \frac{\Delta R / R}{\varepsilon}=(1+2 \mu)+(1-2 \mu)
\end{aligned}
$$

Hubungan $\frac{\Delta R / R}{\varepsilon}$ dikenal sebagai sensitifitas regangan dan sering dilambangkan dengan $K_{g}\left(S_{g}\right)$. Strain gauge dipakai dari tipe FLA-5-3L-11 jenis foil dengan $\mathrm{K}_{\mathrm{g}}=2,14 \pm 1 \%$, panjang $5 \mathrm{~mm}$ dengan tahanan $120 \pm 0,5 \%$ Ohm.

\section{Jembatan Wheatstone}

Strain gauge dirangkai dengan menggunakan jembatan Wheatstone dimana ada empat buah tahanan yaitu : $\mathrm{R}_{1}, \mathrm{R}_{3}$ pada permukaan ring dinamometer diameter luar sedangkan $R_{2}, R_{4}$ pada permukaan diameter 
dalam agar dihasilkan perubahan tegangan $\left(\mathrm{E}_{0}\right)$ maksimum, seperti pada gambar 5 .

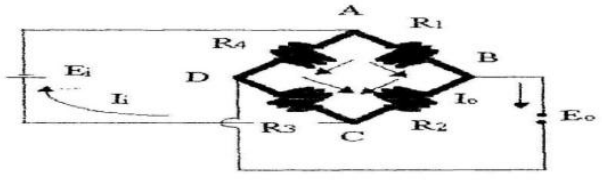

Gambar 5.

Untuk strain gauge diperoleh hubungan antara perubahan tahanan dengan tegangan yang sebanding :

$$
\begin{aligned}
& E_{0}=\frac{E_{i-K_{x}}}{4}\left(\varepsilon_{1}+\varepsilon_{2}+\varepsilon_{2}+\varepsilon_{4}\right) \\
& E_{0}=\frac{E_{i-K_{x}}}{4}\left(\varepsilon_{\text {total }}\right)
\end{aligned}
$$

Harga $\mathrm{E}_{0}$ maksimum dihasilkan pada pemasangan strain gauge yang diatur sedemikian rupa sehingga posisi 1,3 dalara keadaan tarik dan 2,4 dalam keadaan tekan.

\section{Pemasangan Strain Gauge}

Strain gauge dipasangkan pada bagian ring yang akan diukur dengan menggunakan perekat khusus. Perekat harus memenuhi persyaratan sebagai berikut :

- Berkekuatan tinggi

- Daya lekat tinggi

- Berdaya lentur tinggi (dapat mengikuti peregangan ring)

- Tidak mudah retak

- Tidak menyerap air

Umumnya perekat yang dijual dipasaran adalah dari bahan cellulose, phenolic, epoxy dan ceramic. Pada dinamometer ini digunakan perekat loctite 401 dari jenis phenolic.

Untuk pemasangan strain gauge yang baik harus mengikuti langkah-langkah pemasangan sebagai berikut:

- Bagian load cell yang akan ditempel diamplas hingga bersih dari kotoran tapi jangan sampai terlalu licin

- Buat garis posisi pada load cell tempat pemasangan strain gauge agar posisi dan kemiringan peraasangannya tepat.

- Gunakan perekat khusus sesuai dengan jenis strain gauge

- Gunakan plastik anti lekat lem sewaktu penekanan

- Penekanan dilakukan 5 sampai 10 menit untuk kesempumaan penempelan.
- Pengujian sebaiknya dilakukan minimal 24 jam setelah penempelan,

Hal-hal yang diperhatikan saat pemasangan strain gauge adalah :

- Jangan memasang strain gauge saat load cell mengalami regangan atau berbeban

- Pemasangan dilakukan pada suhu kamar

- Yakinkan bahwa posisi perekatan benarbenar mantap

\section{Amplifier}

Sinyal hasil keluaran dari rangkaian strain gauge sangat kecil untuk itu perlu penguat operasional (operational amplifier) agar sinyal keluaran dapat dibaca dengan alat ukur. Strain gauge tipe FLA-5-3L-11 dapat menghasilkan keluaran $1,2 \mathrm{mV}$ pada masukan $4200 \mathrm{rnV}$ dengan tahanan $120 \Omega$. Keluaran 1,2 rnV dihasilkan pada regangan maksimum dari strain gauge. Multimeter sebagai alat ukur dengan kemampuan pembacaan $1 \mathrm{mV}$ tidak dapat mengukur pembahan teganoan keluaran daiam micron Volt.

Agar pengukuran dapat dilakukan dengan data bervariasi dalam orde minimal miliVolt, maka diperlukan penguatan 1000 kali dari sinyal hasil peregangan strain gauge.

\section{Rangka}

Struktur rangka dari alat uji penarikan kawat ini berbentuk batangan baja profil C. Struktur rangka ini dibuat berbentuk vertikal supaya dapat menghemat tempat dan terutama sekali pengujian dapat dilakukan secara vertikal. Alat penarikan kawat tersebut dibuat oleh saudara Very Refrimon (1993) yang merupakan tugas akhir yang bersangkutan.

\section{Dies}

Dies untuk uji penarikan kawat ini diperoleh dari industri penarikan kawat di Cilegon. Dies ini merupakan dies bekas pakai yang masih cukup baik dan masih bisa dimanfaatkan. Kendalanya adalah tingkat reduksi antar masing-raasing dies ini tidak terurut. Hal ini menyebabkan 
penarikan antar tingkat reduksi yang berurutan tidak dapat dilakukan.

\section{Komponen Penggerak}

Untuk menghasilkan gaya penarikan dengan menggunakan motor listrik 3 phasa, daya $1 \mathrm{Hp}$. tegangan input 380 Volt dan putaran 1500 rpm. Untuk mereduksi putaran motor dipakai roda gigi reduksi yang memiliki rasio 1:60, sehingga putarannya menjadi $25 \mathrm{rpm}$, Untuk menarik kawat daya ditransmisikan dengan menggunakan rantai. Sproket yang digunakan menghasilkan putaran sebesar 9 rpm. Sproker yang digerakkan terpasang pada poros yang juga dipasangkan drum untuk menggulung kawat penarik. Kawat penarik dihubungkan pada puli penggerak. Pada ujung kawat penarik ini dipasang ring dinamometer untuk mengukur regangan dan ragum untuk menjepit kawat yang akan ditarik. Kawat penarik yang digunakan adalah kawat baja slink dengan kemampuan tarik sebesar $500 \mathrm{~kg}$.

\section{Prosedur Pengujian}

Prosedur pengujian penarikan kawat adalah sebagai berikut :

- Memasangkan strain gauge pada load cell

- Mengkalibrasi pengukuran

- Melakukan pengujian pada load cell

- Pencatatan hasil pengukuran pada load cell

- Penarikan kawat

Langkah pengujian load cell dapat dilakukan dengan memberikan beban bervariasi. Pembebanan dilakukan bertahap dengan membuka dan menutup katup beban pada mesin uji tarik.

Setiap variasi beban catat perubahan tegangan (voltase) yang dihasilkan. Percobaan ini dilakukan berulang kali untuk mendapatkan hasil yang baik.

Setelah itu proses penarikan kawat dapat dilakukan jika data dan grafik gaya dengan perubahan tegangan didapatkan.

\section{HASIL DAN PEMBAHASAN}

Hasil yang diperoleh dari pengujian penarikan kawat adalah gaya penarikan kawat. Data yang pada pengujian ini dibandingkan dengan gaya penarikan teoritis. Gaya penarikan kawat didapatkan pada pengujian dengan menggunakan dinamometer ring sebagai alat ukur.

\section{Kalibrasi Dinamometer Ring}

Sebelum dinamometer dipakai untuk pengujian terlebih dahulu dilakukan kalibrasi. Kalibrasi dinamometer ring dilakukan dengan memberikan beban bertahap dari beban nol hingga maksimum. Pembebanan bertahap dilakukan dengan membuka dan menutup katup beban pada mesin uji tarik. Setiap tingkat beban yang diberikan, dicatat perubahan tegangan yang keluar dari rangkaian setelah melewati penguat operasional. Untuk memastikan tingkat sensitifitas yang baik, beban bertahap diberikan secara acak Kedua besaran beban dan tegangan disusun untuk membentuk persamaan kalibrasi dengan metoda regresi. Hasil lengkap pengukuran sensitifitas dapat dilihat pada Lampiran B.

Hasil kalibrasi beban dan tegangan hingga beban tarik maksimum 10. 000. N yang ditetapkan, mempunyai perbandingan linier dengan tingkat kepercayaan $98 \%$.

\section{Hasil Pengujian}

Proses penarikan kawat dapat dilakukan setelah data hubungan antara beban (gaya) dengan perubahan tegangan (voltase) dari alat ukur ring dinamometer didapat Langkah pertama adalah persiapan spesimen kawat yang akan ditarik. Proses penarikan dapat dilakukan setelah kawat, dies serta semua peralatan alat ukur telah disiapkan.

Peacatatan perubahan tegangan (voltase) yang keluar selama waktu penarikan kawat dilakukan dengan menggunakan amplifier dan multitester. Besar gaya penarikan kawat yangterjadi dapat diketahui dari kalibrasi ring dinamometer. 
Pengujian penarikan kawat dengan meaggunakan dua jenis material spesimen yaitu : kawat lembaga dan kawat kuningan. Panjang spesimen ini ditetapkan $25 \mathrm{~cm}$. Bentuk dan ukuran spesimen seperti yang tergambar dibawah ini :

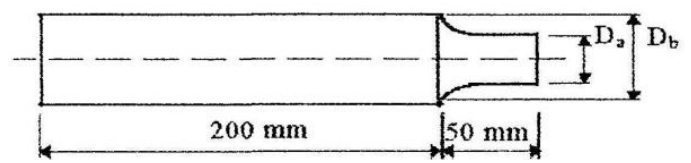

Gambar 6. Spesimen kawat yang akan dideformasi

dideformasi

$\mathrm{D}_{\mathrm{a}}=$ diameter kawat setelah

$D_{b}=$ diameter kawat sebelum dideformasi

Ujung diameter kawat $D_{a}$ sebelum pengujian penarikan kawat dipersiapkan dengan proses gerinda.

Pada penarikan kawat tembaga dilakukan dua kali penarikan secara bertingkat. Ssdangkan pada penarikan kawat kuningan dilakukan hanya pada satu tingkat reduksi karena dies yang tersedia tidak memungkinkan dilakukannya penarikan bertingkat

\section{Gaya Penarikan Teoritis}

Secara teoritis gaya penarikan kawat dapat dinyatakan dengan persamaan :

$F=\overline{\sigma_{0, A_{a}}} \ln \left(\frac{A_{\mathrm{b}}}{A_{\mathrm{a}}}\right)(1+\mu \cot \alpha)$

Dimana :

$\overline{\sigma_{0}}=$ tegangan alir rata-rata pada daerah deformasi

$A_{a}=$ luas penampang kawat sebelum deformasi

$A_{b}=$ luas penampang kawat setelah deformasi

$\mu=$ koefisien gesek

$\alpha=$ sudut setengah cetakan

Gaya penarikan teoritis ini memperhitungkan tegangan alir material kawat, faktor gesekan serta faktor sudut setengah cetakan.

Harga tegangan alir didapatkan dengan melakukan uji tarik terhadap material kawat Nilai koefisien gesek sebesar $\mu=0,1$ yang didapat dan referensi dan besar sudut setengah cetakan $\left(\mathrm{a}=18^{0}\right)$.
Untuk reduksi tingkat 1 pada tembaga

$\mathrm{D}_{\mathrm{b}}==2.25 \mathrm{~mm}, \mathrm{D}_{3}=2 \mathrm{~mm}$

Nilai regangan $\varepsilon_{1}$ adalah :

$\varepsilon_{1}=\ln \left(\frac{A_{b}}{A_{a}}\right)$

$e_{1}=\ln \left(\frac{\pi d_{b} 2 / 4}{\pi d_{\mathrm{a}} 2 / 4}\right)=\ln \left(\frac{\pi 2.25^{2} / 4}{\pi 2^{2 / 4}}\right)=0.24$

Tegangan alir rata-rata dinyatakan dalam bentuk persamaan:

$\overline{\sigma_{0}}=\left(\frac{\mathrm{K} \cdot \varepsilon_{1}^{\mathrm{n}}}{\mathrm{n}+1}\right)$

$\overline{\sigma_{0}}=\frac{31,88 \cdot 0,24^{0,1526}}{0,1526+1}=32,19$

Jadi nilai tegangan alir rata-rata serta konstanta $\mathrm{K}$ dan $\mathrm{n}$ didapatkan dengan melakukan uji tarik lerhadap spesimen kawat (Tabel 4.2).

$\mathrm{F}_{1}=32.19 \cdot\left(\frac{\pi 2,25^{2} / 4}{\pi 2^{2} / 4}\right) \cdot(1+0.1 \cot 18)=59,06$

Gaya Penarikan eksperimental

Data-data perubahan tegangan (voltase) serta besar gaya penarikan kawat dapat dilihat padaTabel 4.1. Besar gaya penarikan kawat ini didapatkan dari perubahan tegangan (voltase) yang keluar (dihasilkan) dari pengujian penarikan kawat.

\section{Analisis}

\section{Tembaga (pengujian gagal)}

Gaya Fp pada penarikan kawat tembaga reduksi pertama untuk 1,2,3,4 (lampiran F) tidak dapat digunakan (data gagal) karena :

1. Pada kasus 1 ujung kawat yang dijepit panjangnya $25 \mathrm{~mm}$ (terlalu pendek), jadi ketika ditarik kawat terlepas.

2. Pada kasus 2 kawat juga terlepas, ini disebabkan permukaan kawat yang digerinda terlalu licin (mudah terlepas). Jadi diusahakan permukaan kawat yang dijepit kasar.

3. Saat terjadi penarikan, kawat yang dijepit patah. Hal ini disebabkan reduksi (pengurangan diameternya) terlalu besar. Diameter kawat sebelum penarikan $\left(D_{b}\right.$ $=2,5 \mathrm{~mm}$ ).

4. $D_{b}=2,35 \mathrm{~mm}, D_{a}=2,00 \mathrm{~mm}$, pada penarikan ini juga masih patah karena proses penarikan tanpa pelumasan. 


\section{Kuningan (pengujian gagal)}

Gaya Fp pada penarikan kawat kuningan untuk data 1,2 (lampiran F) tidak dapat digunakan (data gagal) karena :

1. Pada kasus 1 kuningan ini juga terjadi patah, karena reduksi terlalu besar $\left(D_{b}=\right.$ 4,5 mn, $\left.\mathrm{D}_{\mathrm{a}}=3,9 \mathrm{~mm}\right)$.

2. Penyebab patah disini juga karena tanpa pelumasan $\left(D_{b}=4,3 \mathrm{~mm}, D_{a}=3,9 \mathrm{~mm}\right)$.

\section{Analisa pengujian yang berhasil}

Hasil Pengujian penarikan kawat (tembaga reduksi $1 \mathrm{~F}_{\mathrm{p}}=72,88 \mathrm{kgf}$, tembaga reduksi $2 \mathrm{~F}_{\mathrm{p}}=95,88 \mathrm{kgf}$ dan kuningan $\mathrm{F}_{\mathrm{p}}=$ $102,23 \mathrm{kgf})$. Hasil penarikan kawat teoritis (tembaga. reduksi $1 \mathrm{~F}_{\mathrm{t}}=59,06 \mathrm{kgf}$, tembaga reduksi kedua $\mathrm{F}_{\mathrm{t}}=71,53 \mathrm{kgf}$ dan kuningan $\left.\mathrm{F}_{\mathrm{t}}=126,5 \mathrm{kgf}\right)$. Dari sana dapat terlihat penyimpangan data yang cukup besar antara, percobaan dengan gaya penarikan teoritis, hal ini dipengaruhi oleh beberapa faktor yaitu :

1. Spesimen kawat yang tidak lurus, sehingga pada waktu terjadi penarikan menimbulkan gaya gesek yang cukup besar.

2. Penarikan kawat kurang rata, sehingga menimbulkan gaya gesek cukup besar.

3. Ukuran diameter kawat yaag tidak homogen

4. Pada dinamometer ring pembuatan ulir dalamnya terbuat agak miring (tidak sesumbu).

Fenomena pengerasan regangan (strain hardening) dapat terlihat pada penarikan bertingkat (reduksi yang kedua). Strain hardening terjadi akibat deformasi yang dilakukan dibawah temperatur rekristalisasi (pengerjaan dingin). Pengerasan regangan meuyebabkan naiknya kekerasan, naiknya kekuatan serta turunnya keuleten. Fenornena ini ditunjukkan dengan bertambah besarnya gaya penarikan pada tiap tingkat penarikan berikutnya.

Pada pengujian penarikan kawat tembaga, bertambahnya besarnya gaya penarikan selain disebabkan oleh strain hardening, juga akibat reduksi yang lebih besar pada tingkat penarikan yang kedua. Diameter kawat juga mempengaruhi gaya penarikan kawat. Semakin besar diameter kawat, maka semakin besar gaya penarikan kawat.

Tabel 1. Perbandingan Gaya Penarikan Kawat Percobaan dengan Teoritis

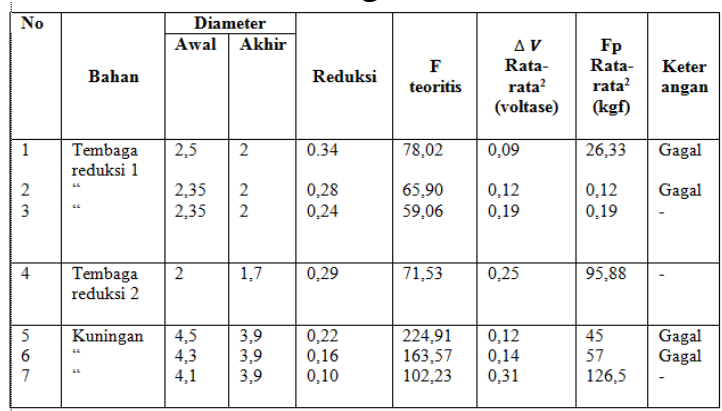

Table 2. Tegangan Alir

\begin{tabular}{|l|l|l|l|l|}
\hline $\mathbf{N}_{0}$ & \multicolumn{1}{|c|}{ Material kawat } & \multicolumn{1}{|c|}{ K } & \multicolumn{1}{|c|}{ n } & \multicolumn{1}{c|}{$\begin{array}{c}\overline{\sigma_{0}} \\
\left(\mathrm{kgf}^{2} \mathrm{~mm}^{2}\right)\end{array}$} \\
\hline 1 & Tembaga reduksi 1 & 31,88 & 0,1526 & 32,19 \\
\hline 2 & Tembaga reduksi 2 & 31,88 & 0,1526 & 35,32 \\
\hline 3 & Kuningan & 58,91 & 0,2385 & 44,76 \\
\hline
\end{tabular}

\section{SIMPULAN}

Setelah dilakukan pengujian dan pengkalibrasian alat ukur ring dinamometer serta pengujian penarikan kawat, dapat diambil kesimpulan sebagai berikut:

Gaya penarikan kawat pada pengujian lebih besar dan gaya penarikan kawat teoritisnya,

Adapun penyebab penyimpanganpenyimpangan antara data percobaan dan teoritis, adalah sebagai berikut :

1. Faktor penguatan (amplifier) tidak terkalibrasi dengan baik (belum tersedianya standar dan pembanding amplifier) dan adanya gangguan pada rangkaian amplifier.

2. Akibat kondisi spesimen tidak lurus dan tidak rata yang menyebabkan faktor gesekan cukup besar.

3. Pemasangan strain gage yang tidak tepat pada posisi $0^{\circ}$ dan posisi $90^{\circ}$ terhadap garis referensi serta pembuatan ulir dalamnya tidak tepat sesumbu.

4. Pembacaan harga tegangan pada multitester yang kurang akurat. 


\section{SARAN}

Melihat adanya kekurangan-kekurangan dari alat ini, maka saran yang dapat diberikan adalah sebagai berikut:

1. Untuk pengujian penarikan kavvat sebaiknya menggunakan amplifier yang telah memiliki standar kalibrasi yang baik.

2. Pembuatan ulir dalam pada dinamometer ring dibuat sesumbu (tegak lurus)

3. Penambahan beban pada pengiyian dinamometer ring dilakukan perlahanlahan dan katup penambahan beban ditutup agak lama sehingga setelah gaya stabil sensitifitas taktor penguatan amplifier dapat membaca dengan ketelitian yang baik.

4. Tempatkan stran gauge di kedudukan yang tepat pada dinamometer ring, usahakan penyimpangan sudut dari garis referensi seminimal mungkin.

5. Untuk keselamatan dan keamanan selama pengujian, perlu ditambahkan pada konstruksi alat uji ini suatu penuntun terhadap ring dinamometer, supaya tidak terbanting jika kawat yang ditarik lepas atau putus.

\section{DAFTAR PUSTAKA}

[1] Boresi, Arthur P, Sidebottom, O.M. Advanced Mechanic of Material, $4^{\text {th }}$ John Wiley \& Sons, Inc, New York, 1985.

[2] Beckwith, T.G ; Buck, N.L.; Marangoni R.D. Pengukuran Mekanis, jilid 1, Erlangga, Jakarta, 1987.

[3] Dieter,G.E. Metalurgi mekanik. edisi ketiga, jilid 2, Erlangga, Jakarta, 1990.

[4] Dieter, G.I, Metalurgi Mekanik, edisi ketiga., jilid 2, Erlangga, Jakarta, 1990

[5] Dafly, James W. Instrumentation for Engineering Measurements. John Wiley \& Sons, Inc, New York, 1985.
[6] Dr. Ir. Marjono Siswosuwarno. Teknik Pembentukan Logam ITB, Bandung, 1985,

[7] Holman, J. P Metoda Penguburan Teknik, edisi kedua, Erlangga, Jakarta, 1984.

[8] Popov, Egor P. Erlangga, Jakarta, 1990. Ozisik, Necati M. and Yildiz, Bayazitoglu, Element of Heat Transfer, Mc Graw-Hill, Singapore, 1988.

[9] Surdia, Tata dan Shinroken, Saito, Pengetahuan Bahan Tehnik, Jakarta, PT. Paradinya Paramita, 1985.

[10] Viack, Lawrence H. Van, Elements of Materials Science and Enginering, $4^{\text {th }}$ edition, Addison-Wesley Publishing Company, USA, 1980. 